\title{
PENGARUH MICRO TEACHING DAN BIMBINGAN GURU PAMONG TERHADAP KEMAMPUAN MENGAJAR MAHASISWA MAGANG PROGRAM STUDI PENDIDIKAN EKONOMI STKIP PGRI TULUNGAGUNG
}

\author{
Sulastri Rini Rindrayani \\ STKIP PGRI Tulungagung \\ rrindrayani@yahoo.com
}

\begin{abstract}
This research is a quantitative research that aims at knowing the effect of micro teaching and guidance from trainee teacher towards apprentice student's teaching ability of Economics Departement of STKIP PGRI Tulungagung. Quesionare is used in data collecting method. The result of data analysis using multiple regression shows (1) There is significant positive effect between micro teaching and the apprentice student's teaching ability, (2) There is significant positive effect between guidance of trainee teacher and the apprentice students' teaching ability. (3) There is positive effect of micro teaching and guidance from trainee teacher towards the apprentice students' teaching ability. The volue of effect is $44,2 \%$, meanwhile $55,8 \%$ is influenced by other factors.
\end{abstract}

Key Words : Microteaching, Guidance From trainee Teacher, Teaching Ability

\begin{abstract}
Abstrak. Penelitian ini merupakan penelitian kuantitatif yang bertujuan untuk mengetahui pengaruh micro teachingdan bimbingan guru pamong terhadap kemamupan megajarn mahasiswa magang Program Studi Pendidikan Ekonomi STKIP PGRI Tulungagung. Metode pengumpulan data menggunakan kuesioner. Hasil analisis data dengan menggunakanstatistik regresi linier berganda terbukti (1) ada pengaruh positif yang signifikan antara micro taching dengan kemampuan mengajar mahasiswa magang, 2) ada pengaruh positif yang signifikan antara pembimbingan guru pamong terhadap kemampuan mengajar mahasiswa magang, dan 3) ada pengarug positif anatar micro teacing dan bimbingan guru pamong terhadap kemampuan mengajar mahasiswa magang. Besar pengaruh secara simultan adalah $44,2 \%$ sedangkan sebesar 55,8\% dipengaruh faktor lain.
\end{abstract}

Kata Kunci : Micro Teaching, Bimbingan Guru Pamong, dan Kemampuan Mengajar

\section{PENDAHULUAN}

Untuk menghasilkan tenaga

pendidikyang profesional dan berkompeten STKIP PGRI

Tulungagung membekali mahasiswa pembelajaran micro teaching dan magang yang keduanya merupakan mata kuliah wajib. Mahasiswa akan mengambil mata kuliah micro teaching pada semester 5 dan mata kuliah magang pada semester 7 . Mata kuliah micro teaching sebagai mata kuliah prasyarat untuk menempuh mata kuliah magang.

$$
\text { Pengajaran mikro atau }
$$

Microteaching adalah merupakan suatu teknik atau metode latihan yang dirancang untuk 
mengembangkan ketrampilan

mengajar, baik dalam ketranpilan-

ketrampilan baru, maupun

ketrampilan-ketampilan lama yang

dimiliki oleh calon guru, yang dilakukan dengan cara

mengesolasikan komponen-

komponen ketrampilan mengajar,

sehingga setiap komponen

ketrampilan mengajar tersebut dapat

dikuasai dengan baik oleh calon guru

dalam situasi dan kondisi pengajaran

yang disederhanakan atau

dimikrokan" (Sulthon, 2009 :19).

Sementara Das Salirawati

(2011), Micro teaching merupakan sarana latihan untuk berani trampil menghadapi kelas dengan peserta didik yang beraneka ragam karakternya, mengendalikan emosi, ritme pembicaraan, mengelola kelas agar kondusif untuk proses transfer ilmu, dan lain-lain

Situasi dan kondisi pengajaran yang disederhanakan atau dimikrokan tersebut adalah meliputi baik dari segi ketrampilan mengajarnya (1-2 komponen ketrampilan), jumlah siswa (5 - 10 orang siswa), waktu mengajar (5 15 menit), manun dari segi bahan pengajaran(1-2 aspek atau unit yang disederhanakan)". (sulthon, 2006, 2009 : 19)

Menurut Sulthon (2009: 28) beberapa ketrampilan dasar mengajar yang harus dikuasai seorang calon guru dalam berlatih mengajar melalui kegiatan pengajaran mikro, meliputi: 1) ketrampilan membuka dan menutup pelajaran, 2) ketrampilan menjelaskan,3) ketrampilan mengadakan variasi pengajaran, 4) ketrampilan mengelola kelas, 5) ketrampilan bertanya, 6) ketrampilan memberi penguatan, 7) ketramplan mengajar kelompok kecil dan perorangan, dan 8) ketrapilan memimpin diskusi kelompok kecil.Keterampilan mengajar itu harus dikuasai sehingga diperlukan latihan yang sitematis. Dengan adanya micro teaching diharapkan mahasiswa mempunyai bekal untuk persiapan pada saat terjun ke lapangan. Hal ini senada dengan penelitian Manzoor dan Masrur(2011), menyatakan bahwa guru yang dilatih performanya lebih baik dalam keterampilan bertanya, mendengarkan, memberikan umpan balik, dan merancang pembelajaran

Magang/Pengalaman Lapangan (PPL) menurut Wardani \& Suparno (1994:2) "adalah salah satu program dalam pendidikan prajabatan guru yang dirancang khusus untuk menyiapkan para calon guru menguasai kemampuan keguruan yang terintegrasi dan utuh, sehingga setelah menyelesaikan pendidikannya dan diangkat menjadi guru, maka siap mengemban tugas dan tanggung jawabnya sebagai guru."Sedangkan pengertian PPL menurutDasmo \& Sumaryati (2014: 57), Astuti dkk (2013: 3), adalah merupakan salah satu kegiatan akademik yang bersifat intrakurikuler yang mencakup latihan mengajar dan tugas-tugas kependidikan lainnya secara terbimbing, terarah dan terpadu untuk memenuhi persyaratan 
pembentukan tenaga professional dalam kependidikan.

$$
\text { Kegiatan magang di STKIP }
$$

PGRI Tulungagung dilakukan

melalui dua tahap pelkasanaan.

Tahap pertama pemberian

pembekalan magang di kampus dan tahap ke dua pelaksanaan magang di sekolah-sekolah mitra, yaitu SMP,SMA dan SMK. Pada pembekalan magang mahasiswa diberikan materi cara membuat perencanaan, penerapan metode pembelajaran, dan penialian pembelajaran berdasarkan kurikulum KTSP dan kurikulum 2013, serta bagaimana meidentifikasi kondisi sekolah. Sedangkan pada magang tahap dua mahasiswa praktik di sekolah-sekolah. Pada magang tahap dua ini terbagi menjadi tiga magang, magang pertama yang dilakukan selama satu minggu, bertujuan untuk memberikan ketrampilan pada mahasiswa mampu mengidentifikasi kondisi sekolah baik pada prasarana, kurikulum yang digunakan, kondisi guru, dan siswa. Tagihan mahasiswa berupa laporan observasi sekolah yang ditempati dan mempresentasikan hasil observasi di dalam kelas.

Dilanjutkan pelaksanaan magang ke dua selama satu minggu yang bertujuan untuk memberikan ketrampilan mahasiswa membuat perangkat pembelajaran sesuai mata pelajaran yang akan diajarkan. Perangkat pembelajaran meliputi Program semester, program tahunan, rencana Pelaksanaan Pembelajaran (RPP), Media pembelajaran, Materi pembelajaran, dan alat evaluasi pembelajaran. tahigan pada magang ke dua ini mahasiswa mengumpulkan analisis RPP yang digunakan oleh guru tempat magang, RPP mata pelajaran yang digunakan untuk mengajar, dan presentasi hasil evaluasi RPP di dalam kelas. Magang ke dua selesai berselang satu minggu dilanjutkan magang ke tiga selama empat minggu. Pada magang ke tiga ini mahasiswa praktik mengajar sebagai asisten mengajar sebanyak minimal lima kali sebagai asisten mengajar. Pelaksanaan asisten mengajar ini akan dinilai oleh guru pamong dan teman dengan menggunakan format pelaksanaan pembelajaran yang sudah disiapkan. Hasil penilaian dengan menggunakan lembar pengamatan tadi kemudian dilakukan refleksi oleh guru pamong dan teman satu tim. Refleksi mefokuskan pada kekurang dan kebaikan pelaksanaan pembelajaran, disertai tindak lanjut yang harus dilakukan oleh peseta yang diamati. Dari gambaran ini jelas magang dapat memberikan ketrampilan mengajar dan membuat perangkat pembelajaran sehingga mempunyai kemapuan mengajar dengan baik.

$$
\text { Mengingat pelaksanaan }
$$

magang merupakan suatu sistem, maka keberhasilannya tidak hanya didukung oleh micro teaching saja. Namun ada faktor lain yang menjadi pengaruh kemampuan mahasiswa pada saat magang, salah satunya adalah guru pamong. Peran guru pamong dalam memberikan bimbingan dapat mempengaruhi 
mahasiswa dalam melaksanakan magang. Dengan adanya bimbingan guru pamong, mahasiswa dapat memperbaiki dan memotivasi diri dalam melaksanakan magang dengan sebaik-baiknya Sebaliknya, bila guru pamong dalam memberikan bimbingan kepada mahasiswa magang kurang lancar maka prestasi yang dicapaipun kurang memuaska. Pada intinya, peran guru pamong adalah salah satu faktor terpenting dalam menunjang pelaksanaan dan keberhasilan magang. Hal ini sesuai penelitian yang dilakukan oleh Sumaryati (2014: 56) yang membuktikan bahwa terdapat pengaruh peran guru pamong dan dosen pembimbing secara bersamasama terhadap keberhasilan PPL mahasiswa dengan pengaruh yang sedang".

Hasil Penelitian yang dilakukan Saputri, Dea Natalia dkk, (2013), membuktikan bahwa terdapat pengaruh yang positif persepsi mahasiswa tentang micro teaching danbimbingan guru pamong terhadap kemampuan mengajar mahasiswa PPL. Penelitian yang sama dilakukan oleh Amin (2015) membuktikan bahwa terdapat pengaruh yang positif dan signifikan prestasi belajar micro teaching dan bimbingan guru pamong terhadap kemampuan mengajar PPL. Penelitian yang dilakukan oleh Ni'mah dan Oktarina (2014 : 336) juga membuktikan bahwa ada pengaruh positif yang signifikan antara peran guru pamong dan prestasi belajar terhadap kesiapan mahasiswa menjadi guru.
Beradarkan kajian dan penelitian terdahulu membuktikan pentingnya memberikan pembelajaran micro teaching yang optimal sehingga mahasiswa dapat menguasai ketrampilan dasar mengajar dengan baik sebagai bekal untuk praktik mengajar di sekolah-sekolah atau magang. Di samping itu pentingnya peran guru pamong dalam memberikan bimbingan dalam pelaksanaan magang sehingga peserta magang dapat praktik mengajar dengan baik. berdasarkan permasalah tersebut, peneliti akan mengkaji pengaruh micro teaching dan bimbingan guru pamong terhadap kemampuan mengajar mahasiswa magang Program Studi Pendidikan Ekonomi STKIP PGRI Tulungaagung

Sesuai latar belakang masalah maka tujuan penelitian ini adalah1) Untuk mengetahui adakah pengaruh micro teaching terhadap kemampuan mengajar mahasiswa magang Program studi Pendidikan Ekonomi STKIP PGRI Tulungagung.2) Untuk mengetahui adakah pengaruh bimbingan guru pamong terhadap kemampuan mengajar mahasiswa magang Program studi Pendidikan Ekonomi STKIP PGRI Tulungagung, 3) Untuk mengetahui adakah pengaruh micro taching dan bimbingan guru pamong terhadap kemampuan mengajar mahasiswa magang Program studi Pendidikan Ekonomi STKIP PGRI Tulungagung. 


\section{METODOLOGI PENELITIAN}

Populasi dalam penelitian ini adalah mahasip Pogram studi pendidikan ekonomi semester VIII yang telah menempuh mata kuliah micro teaching dan magang sejumlah 120 mahasiswa. Tenik sampling menggunakan proposional random sampling 50\% dari jumlah populasi. Jumlah sampel sebesar 60 mahasiswa.

Variabel bebas dalam penelitian ini adalah micro teaching (X1) dan bimbingan guru pamong (X2) dan variable terikat kemampuan mengajaran (Y). Mikro teaching dalam penelitian ini adalah latihan mengajar yang situasi dan kondisinya disederhanakan untuk berlatih mengembangkan ketrampilan dasar mengajar secara terpisaha tau terisolasi. Pengusaan ketrampilan dasar dalam pembelajaran micro meliputi: 1) ketrampilan membuka dan menutup pelajaran, 2) ketrampilan menjelaskan, 3)ketrampilan mengadakan variasi pengajaran, 4) ketrampilan mengelola kelas, 5) ketrampilan bertanya, 6) ketrampilan memberi penguatan, 7) ketramplan mengajar kelompok kecil dan perorangan, dan 8)ketrapilan memimpin diskusi kelompok kecil

Guru pamong adalah guru yang ditunjuk dengan surat tugas sebagai guru pamong untuk memberikan bimbingan kepada peserta magang selama pelaksanaan magang. Bimbingan yang dilakukan oleh guru pamong kepada peserta magang meliputi: 1)Memberikan bimbingan teknis pelaksanaan kegiatan magang 2)Melakukan koordinasi dengan Kepala Sekolah, Dosen Pembimbing Magang (DPM), dan mahasiswa bimbingannya dalam pelaksanaan kegiatan magang dan 3)Menilai proses pembelajaran (asistensi) mahasiswa peserta magang

Kemampuan mahasiswa magang dalam penelitian ini adalah kemampuan mahasiswa praktik magang yang dapat dilihat dari kemampuan dalam 1) membuat RPP, 2) melaksanakan pembelajar sebagai asisten, dan 3) melakukan refleksi pada teman sejawat. Adapun Variabel, Indikator dan metode pengumpulan data dapat di lihat pada Tabel 1.

Metode pengumpulan data menggunakan angket. Metode angket digunakan untuk mengumpulkan data tentang kemampuan melaksanakan micro teching(X1), bimbingan guru pamong (X2), dan kemampuan melaksanakan mengajar mahasiswa magang (Y).Penelitian ini menggunakan metode angket jenis angket tertutup, yaitu pertanyaan sudah disediakan jawabanya, responden tinggal memilih salah satu jawaban yang diagap sesuai. Instrumen menggunakanpengukuran skala likert. Selalu (SS) diberi skor 4, Sering (SR) diberi skor 3, Kadangkadang (KD) diberi Skor 2, dan Tidak Pernah (TP) diberi skor 1.

Sedangkan untuk mengetahui kreteria penilaian pada variabel micro teaching (X1), guru pamong (X2) dan kemampuan mengajar 
mahasiswa magang (Y) adalah sebagai berikut;

Tabel 2: Kreteria Nilai Micro Teaching, Bimbingan Guru Pamong dan Kemampuan Mengajar

\begin{tabular}{|c|c|c|}
\hline No & Nilai & Klasifikasi \\
\hline 1 & $86-100$ & Sangat baik \\
\hline 2 & $71-85$ & Baik \\
\hline 3 & $60-70$ & Cukup baik \\
\hline 4 & $20-59$ & Kurang baik \\
\hline
\end{tabular}

Sumber : Peneliti

Analisis data dalam penelitian ini menggunakan analisis statistik regresi linier berganda.

\section{HASIL ANALISIS DATA}

\section{Uji Validitas dan Realibilitas} Instrumen

Tabel 3: Uji Validitas Instrumen (pada lampiran)

Berdasarkan tabel 3 menunjukkan bahwa semua item pertanyaan pada angket pada variabel micro teaching (X1), bimbingan guru pamong (X2) dan kemampuan mengajar mahasiswa magang (Y) adalah valid, hal ini terbukti besar $r$ hitung $<r$ tabel 0,254 dan Alpha hitung 0,000 < 0,05

Tabel 4: Uji Reliabilitas Intrumen

\begin{tabular}{|l|l|c|c|}
\hline No & Variabel & $\begin{array}{l}\text { Cronbach's } \\
\text { Alpha }\end{array}$ & Keputusan \\
\hline A & Micro Teaching (X1) & \multicolumn{2}{|l|}{} \\
\hline 1 & $\begin{array}{l}\text { X1.1 Ketrampilan } \\
\text { Membuka }\end{array}$ & 0,698 & Reliabel \\
\hline 2 & X1.2 Ketrampilan & 0,692 & Reliabel \\
\hline
\end{tabular}

\begin{tabular}{|c|c|c|c|}
\hline & Menutup & & \\
\hline 3 & $\begin{array}{l}\text { X1.3 Ketrampilan } \\
\text { Menjelaskan }\end{array}$ & 0,709 & Reliabel \\
\hline 4 & $\begin{array}{l}\text { X1.4 Ketrampilan } \\
\text { Pengelolaan Kelas }\end{array}$ & 0,734 & Reliabel \\
\hline 5 & $\begin{array}{l}\text { X1.5Ketrampilan } \\
\text { Bertanya }\end{array}$ & 0,745 & Reliabel \\
\hline 6 & $\begin{array}{l}\text { X1.6Memberikan } \\
\text { penguatan }\end{array}$ & 0,848 & Reliabel \\
\hline 7 & $\begin{array}{l}\text { X1.7Ketrampilan } \\
\text { Mengajar Kel. Kecil }\end{array}$ & 0,730 & Reliabel \\
\hline 8 & $\begin{array}{l}\text { X1.8 Ketrampilan } \\
\text { membimbing Diskusi }\end{array}$ & 0,718 & Reliabel \\
\hline B & $\begin{array}{l}\text { Bimbingan Guru Pamong } \\
\text { (X2) }\end{array}$ & 0,632 & Reliabel \\
\hline $\mathrm{C}$ & \multicolumn{3}{|c|}{ Kemampuan Mengajar Mahasiswa Magang (Y) } \\
\hline 1 & Membuat RPP (Y1.1) & 0,711 & Reliabel \\
\hline 2 & $\begin{array}{l}\text { Melaksanakan } \\
\text { Pembelajaran(Y1.2) }\end{array}$ & 0,673 & Reliabel \\
\hline 3 & Refleksi (Y1.3) & 0,750 & Reliabel \\
\hline
\end{tabular}

Sumber: Hasil Analisis Data Menggunakan SPSS.

Berdasarkan tabel 4 merupakan hasil analisis data untuk mengetahui reliabilitas dengan bantuan SPSS, bahwavariable micro teaching $\mathrm{X} 1$ ), Pembingan guru pemong (X2) dan kemampuan mengajar mahasiswa magang (Y)menunjukkan seluruh item soal diperoleh Cronbach's alpha $>$ 0,600. Jadi dapat disimpulkan bahwa seluruh item soal variabelmicro teaching (X1), Pembingan guru pemong (X) dan kemampuan mengajar mahasiswa magang (Y) dinyatakan reliabel dan dapat digunakan sebagai instrument tes untuk mencari data dalam penelitian ini 


\section{Uji Prasyarat Regresi Linier Berganda}

\section{Uji Normalitas}

Dalam pengujian normalitas data pada penelitian ini menggunakan grafik histogram yaitu dengan melibatkan kecenderungan sebaran data terhadap garis regresi. Apabila data hasil kuesioner yang dilakukan penyebaran data ada disekitar garis regresi, maka data dikatakan berdistribusi secara normal sehingga prasyarat normalitas terpenuhi dan layak untuk dipergunakan dalam analisis lebih lanjut melalui grafik histogram sebagai berikut:

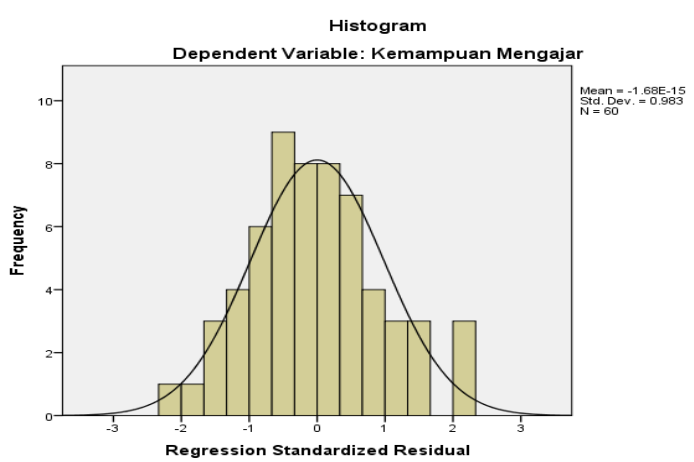

Hasil Uji Normalitas Histogram

\section{Uji linieritas}

Pengujian linieritas pada penelitian ini digunakan untuk mengetahui status linier tidaknya suatu distribusi data penelitian, dimana uji linieritas dalam penelitian ini menggunakan diagram Normal P$\mathrm{P}$ plot dengan memberikan tambahan garis regresi.Oleh karena itu menampilkan hubungan tiga variabel, apabila garis regresi pada grafik mengarah dari kiri bawah kekanan atas maka asumsi linieritas terpenuhi.Berdasarkan normal probality plot bahwa data memiliki kesamaan atau linier dibuktikan dengan titik-titik pada garis dan mengikuti garis linier.

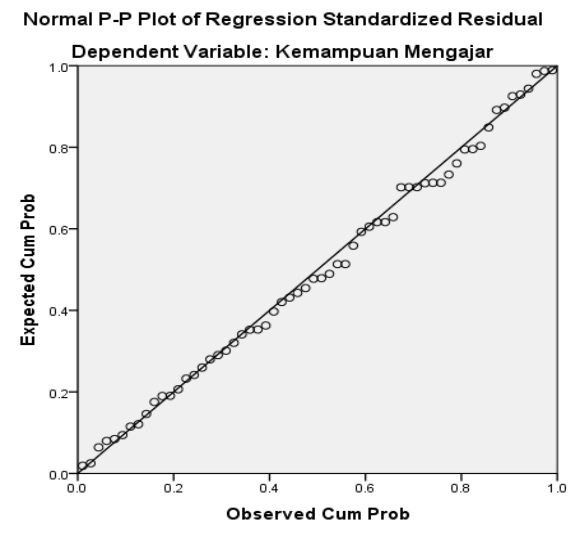

Gambar 1 : Uji Linieritas

\section{Uji Multikolinieritas}

Uji multikolinearitas digunakan untuk menguji apakah Jada model regresi ditemukan xdanya korelasi antar variable ndependent. Jika terjadi korelasi naka terdapat problem nultikolinearitas.Model regresi yang saik yaitu tidak terjadi korelasi antar variabel bebas. Pedoman untuk model regresi linier bebas dari korelasi adalah dapat dilihat melalui VIF (Variant Independent Faktor).Model regresi yang multikolinearitas adalah (1) mempunyai nilai VIF disekitar angka 1, (2) mempunyai angka tolerance mendekati 1 . 
Tabel 5: Multiliniritas

Coefficients $^{a}$

\begin{tabular}{|c|c|c|c|c|c|c|c|c|c|c|}
\hline \multirow[t]{2}{*}{ Model } & \multicolumn{3}{|c|}{$\begin{array}{c}\text { Unstandardized } \\
\text { Coefficients }\end{array}$} & \multicolumn{2}{|c|}{$\begin{array}{c}\text { Standardized } \\
\text { Coefficients } \\
\end{array}$} & & \multirow[t]{2}{*}{ Sig } & \multicolumn{3}{|c|}{ Collinearity Statistics } \\
\hline & $\mathrm{B}$ & Std. & Error & & Beta & & & Tol & & \\
\hline (Constant) & & 763 & & 785 & & & 4.208 & .000 & & \\
\hline Micro Teacching & & 455 & & 92 & & .510 & 4.930 & .000 & 883 & $\begin{array}{l}1.1 \\
32\end{array}$ \\
\hline $\begin{array}{l}\text { Pembimbingang Guru } \\
\text { Pamong }\end{array}$ & & 181 & & 061 & & .306 & 2.960 & .004 & .883 & $\begin{array}{r}1.1 \\
32\end{array}$ \\
\hline
\end{tabular}

a. Dependent Variable: Kemampuan Mengajar

Berdasarkan pada tabel diatas dapat dilihat bahwa besaran VIF $(1,132 ; 1,132)$ berada disekitar angka 1 dan tolerance $(0,883 ; 0,883)$ disekitar angka 1, sehingga dapat dikatakan bahwa model regresi tidak terdapat problem multikolinieritas.

\section{Uji Heteroskedastisitas}

Untuk mendeteksi suatu instrument terdapat heterokedastisitas yaitu dengan melihat ada tidaknya pola pada grafik regresi, jika ada maka telah terjadi Heterokedastisitas dan jika tidak ada pola yang jelas atau polanya menyebar diatas dan dihavah anoka $\mathrm{O}$ nada cumhı $\mathrm{Y}$

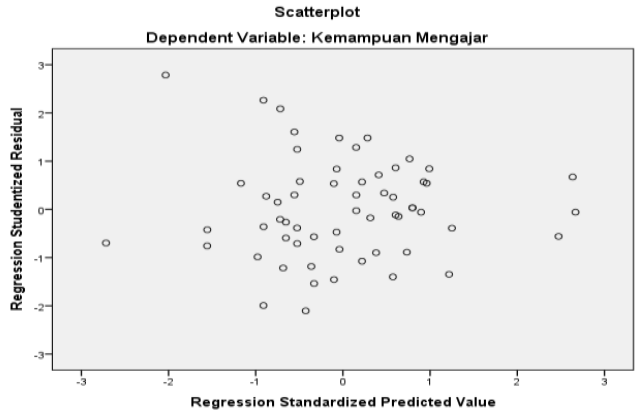

Gambar 2: Uji Heteroskedastisitas Diskripsi Variabel Penelitian

Berdasarkan pengupulan data dengan menggunakan angket dan analisis data, pada micro teaching membuktikan bawah mahasiswa magang dalam pelaksanaan micro teaching (X1) mempunyai nilai ratarata 85,50 dalam kategori nilai baik, Bimbingan guru pamong (X2) mempunyai nilai rata-rata 83,83 dalam kategori nilai baik, dan kemampuan mengajar mahasiswa magang (Y) mempunyai nilai ratarata 86,65 dalam kategori sangat baik.

\section{Analisis Regresi Linier Berganda}

Pengaruh Secara parsial

Tabel 6: Uji Pengaruh Parsial

\begin{tabular}{|c|c|c|c|c|c|}
\hline \multirow[t]{2}{*}{ Model } & \multicolumn{2}{|c|}{$\begin{array}{l}\text { Unstandardize } \\
\text { d Coefficients }\end{array}$} & \multirow{2}{*}{$\begin{array}{c}\begin{array}{c}\text { Standardiz } \\
\text { ed } \\
\text { Coefficient } \\
\text { s }\end{array} \\
\text { Beta }\end{array}$} & \multirow[t]{2}{*}{$\mathrm{t}$} & \multirow[t]{2}{*}{ Sig. } \\
\hline & B & $\begin{array}{l}\text { Std. } \\
\text { Error }\end{array}$ & & & \\
\hline (Constant) & $\begin{array}{r}32.76 \\
3\end{array}$ & 7.785 & & $\begin{array}{r}4.2 \\
08\end{array}$ & .000 \\
\hline $\begin{array}{l}\text { Micro } \\
\text { Teacching }\end{array}$ & .455 & .092 & .510 & $\begin{array}{r}4.9 \\
30\end{array}$ & .000 \\
\hline $\begin{array}{l}\text { Pembimbin } \\
\text { gang Guru } \\
\text { Pamong }\end{array}$ & .181 & .061 & .306 & $\begin{array}{r}2.9 \\
60\end{array}$ & .004 \\
\hline
\end{tabular}

a. Dependent Variable: Kemampuan Mengajar

Uji t digunakan untuk menghitung pengaruh secara parsial hubungan variabel bebas terhadap variabel 
terikat. Berdasarkan hasil analisis data menggunakan SPSS (Tabel :6) menjujukan bahwa Nilai $t$ Hitung $(4,930)>\mathrm{t}$ Tabel $(2,000)$ serta tingkat signifikansi $0,000<0,05$. Dengan demikian Ho ditolak dan $\mathrm{Ha}$ diterima. Sehingga, dapat disimpulkan bahwa ada pengaruh positip yang signifikan antara micro teaching terhadap kemampuan mengajar mahasiswa magang Program Studi Pendidikan Ekonomi.

Hasil analisis menunjukkan bahwa nilai $\mathrm{t}_{\text {Hitung }}(2,960)>\mathrm{t}_{\text {Tabel }}(2,000)$ serta tingkat signifikansi $0,000<$ 0,05 . Dengan demikian Ho ditolak dan $\mathrm{Ha}$ diterima. Sehingga, dapat disimpulkan bahwa ada pengaruh positip yang signifikan antarabimbingan guru pamong terhadap kemampuan mengajar mahasiswa magang Program Studi Pendidikan Ekonomi

Dari hasil analisis regresi berganda diatas dapat dilihat bahwa diperoleh persamaan $Y=a+b_{1} X_{1}+b_{2} X_{2}$ dan berdasarkan pengamatan nilai $\mathrm{a}, \mathrm{b} 1$, b2, secara berturut-turut dari atas

bisa dilihat pada baris Unstandarized Coefficients B pada Tabel Coefficient, dapat diperoleh nilai a= 32,763 , nilai $\mathrm{b} 1=0,455$, dan nilai b2 $=0,181$

Selanjutnya, nilai a, nilai b1, dan nilai b2 dimasukkan ke dalam persamaan garis regresi sehingga dapat disusun persamaan $\mathrm{Y}$ $=32,763+0,455 \mathrm{X}_{1+} 0,181 \mathrm{X}_{2}$ dengan penjelasan sebagai berikut: 1) merupakan konstanta yang besarnya 32.763 menyatakan bahwa jika variabel independen (micro taching dan bimbingan guru pamong) sebesar 0 (nol), maka nilai variabel dependen (kemampuan mengajar mahasiswa magang) sebesar 32.763. 2) b1 merupakan koefisien regresi dari $\mathrm{X}_{1}$ (micro teaching). Koefisien regresi 0,455 menyatakan bahwa setiap penambahan satu satuan variabel $\mathrm{X}_{1}$ (micro teaching) dengan asumsi variabel lain $\left(\mathrm{X}_{2}\right)$ dianggap konstan maka hal ini akan berpengaruh pada peningkatan besarnya $\mathrm{Y}$ (kemampuan mengajar mahasiswa magang) sebesar 0.455 . 3) b2 merupakan koefisien regresi dari $\mathrm{X}_{2}$ (pemanfaatan perpustakaan). Koefisien regresi 0, 181 menyatakan bahwa setiap penambahan satu satuan variabel $\mathrm{X}_{2}$ (pembingan guru mamong) dengan asumsi variabel lain $\left(\mathrm{X}_{1}\right)$ dianggap konstan maka hal ini akan berpengaruh pada peningkatan besarnya $\mathrm{Y}$ (kemampuan mengajar mahasiswa mag ) sebesar 0, 369.

Tabel 7: Uji Pengaruh Secara Simultan

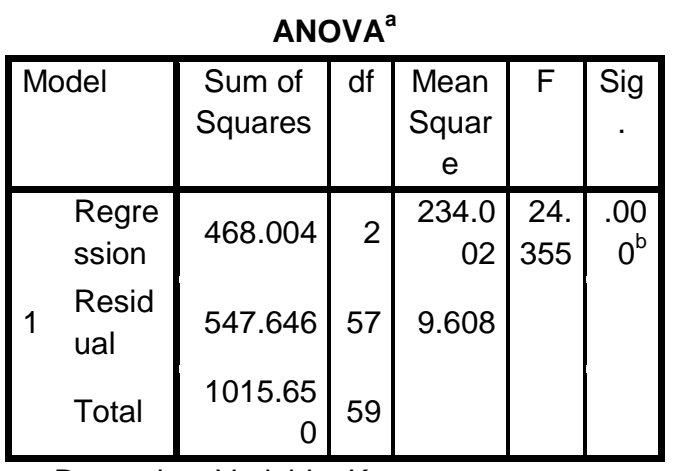

a. Dependent Variable: Kemampuan

Mengajar

b. Predictors: (Constant), Pembimbingang

Guru Pamong, Micro Teacching 
Tabel 7 merupakan hasil analisis untuk mengetahui pengaruh sevara bersama-sama antara variabel bebas dengan variabel terikat. Pada tabel 7 menunjukkan bahwa besar $\mathrm{F}$ hitung $=24.355>\mathrm{F}$ tabel 19,47.dan tingkat signifikansi $0,000<0,05$ maka Ho ditolak dan Ha diterima. Hal ini menunjukkan bahwa ada pengaruh positip yang signifikan antaramicro teaching (X1) dan bimbungan guru pamong (X2) terhadapkemampuan mengajar mahasiswa magang Program Studi Pendidikan Ekonomi STKIP PGRI Tulungagung.

Tabel 8: Model Summary ${ }^{b}$

\begin{tabular}{|l|r|r|r|r|}
\hline $\begin{array}{l}\text { Mode } \\
\mathrm{I}\end{array}$ & $\mathrm{R}$ & $\begin{array}{c}\mathrm{R} \\
\text { Square }\end{array}$ & $\begin{array}{r}\text { Adjusted } \\
\text { R Square }\end{array}$ & $\begin{array}{r}\text { Std. Error } \\
\text { of the } \\
\text { Estimate }\end{array}$ \\
\hline 1 & $\begin{array}{r}.67 \\
9^{\mathrm{a}}\end{array}$ & .461 & .442 & 3.100 \\
\hline
\end{tabular}

a. Predictors: (Constant), Pembimbingang Guru Pamong, Micro Teacching b. Dependent Variable: Kemampuan Mengajar

Berdasarkan tabel 8, indeks determinasi untuk $\mathrm{X}_{\mathrm{I}}$ dan $\mathrm{X}_{2}$ terhadap $\mathrm{Y}$ sebesar 0,442. Nilai tersebut dirubah menjadi bentuk prosentase maka hasilnya adalah $44,2 \%$. Jadi dapat disimpulkan besarnya pengaruh yang signifikan antaramicro teaching (X1) dan Bimbungan guru pamong (X2 ) terhadapkemampuan mengajar mahasiswa magang program studi pendidikan ekonomi STKIP PGRI Tulungagung sebesar 44,2 sedangkan sebesar 55,8\% dipengaruhi oleh faktor lain.

\section{PEMBAHASAN}

Hasil analalisis data membuktikan bahwa ada pengarug positip yang sangat signifikan antara micro teaching (X1) terhadap kemampuan mengajar mahasiswa magan Progran Studi Pendidikan Ekonomi STKIP PGRI Tulungagung. Hal ini dapat diartikan bahwa apabila nilai micro teaching baik maka akan diikuti kemampuan mengajar mahasiswa baik. Artinya bahwa mahasiswa dalam pelaksanaan pembelajaran micro teaching mahasiswa sudah dapat menerapkan delapan ketrampilan dasar mengajar meliputi ketrampilan membuka pelajaran, menutup pelajran, menjelaskan, pengelolaan kelas, ketramplan bertanya, memberikan penguatan, mengajar kelompok kecil, dan membimbing diskusi dengan baik. Delapan Ketrampilan dasar yang dapat dilakukan dengan baik ini berakibat pada kemampuan mengajar pada kegiatan magang dapat dilaksanakan dengan baik, yaitu dalam membuat RPP, melaksanakan pembelajaran, dan refleksi.

Hasil penelitian ini mendukung teori Sulthon (2009: 28) beberapa ketrampilan dasar mengajar yang harus dikuasai seorang calon guru dalam berlatih mengajar melalui kegiatan pengajaran mikro, meliputi: 1) ketrampilan membuka dan menutup pelajaran, 2) ketrampilan menjelaskan,3) ketrampilan mengadakan variasi pengajaran, 4) ketrampilan mengelola kelas, 5) ketrampilan 
bertanya, 6) ketrampilan memberi penguatan, 7) ketramplan mengajar kelompok kecil dan perorangan, dan 8) ketrapilan memimpin diskusi kelompok kecil. Keterampilan mengajar itu harus dikuasai sehingga diperlukan latihan yang sitematis. Dengan adanya micro teaching diharapkan mahasiswa mempunyai bekal untuk persiapan pada saat terjun ke lapangan. Hasil penelitian ini juga mendukung penelitian yang dilakukan oleh Dea Natalia Saputri,dkk (2013) terdapat pengaruh yang positif persepsi mahasiswa tentang micro teaching terhadap kemampuan mengajar mahasiswa PPL.

Hasil analisis data membuktikan bahwa ada pengaruh positip yang signifikan antara bimbingan guru pamong (X2) terhadap kemampuan mengajara mahasiswa magang Program Studi Pendidikan Ekonomi STKIP PGRI Tulungagung. Hal ini dapat diartikan bahwa apabila bimbingan guru pamong dilakukan secara baik maka kemampuan mengajar mahasiswa magang juga baik. Juga dapat diartikan bahwa guru pamong di sekolah tempat magang mahasiswa STKIP PGRI Tulungagung sudah memberikan bimbingan kepada mahasiswa Prodi Pendidikan Ekonomi dengan baik, meliputi membimbing pembuatan RPP, membimbing dan melakukan evaluasi pelaksanaan pembelajaran mahasiswa, dan memberikan refleksi untuk merekomendasi kemampuan mahasiswa dalam praktik mengajar.
Bimbingan guru pemong yang baik ini mempengaruhi pelaksanaan magang dapat dilakukan mahasiswa dengan baik.

Hasil penelitian ini
mendukung teori Ni'mah dan Oktarina (2014 : 338) yang menjelaskan Guru pamong sebagai master teacher yang membimbing mahasiswa dalam melaksanakan tugas - tugas guru. Guru pamong akan membantu mahasiswa dalam mempersiapkan diri menjadi seorang guru misalnya dengan berbagi pengalaman tentang mengajar yang telah diperolehnya. Pendapat lain dari Natalia S (2013, 5-6) Peran guru pamong dalam memberikan bimbingan dapat mempengaruhi mahasiswa dalam melaksanakan PPL. Dengan adanya bimbingan guru pamong, mahasiswa dapat memperbaiki dan memotivasi diri dalam melaksanakan PPL dengan sebaik-baiknya Sebaliknya, bila guru pamong dalam memberikan bimbingankepada mahasiswa PPL kurang lancar maka prestasi yang dicapaipun kurang memuaskan. Hasil penelitian ini juga mendukung penelitian yang dilakukan olehAmin Fadly (2015) dan Dea Natalia Saputri, dkk (2013) membuktikan bahwaterdapat pengaruh yang positif dan signifikan bimbingan guru pamong terhadap kemampuan mengajar PPL.

Hasil analisis data juga membuktikan ada pegaruh positip yang signifikan antara micro tacing dan bimbingan guru pamong terhadap kemampuan mengajar 
mahasiswa magang Program Studi Pendidikan Ekonomi STKIP PGRI Tulungagung. Penelitian ini mendukung penelitian yang dilakukan olehDea Natalia Saputri, dkk (2013) yang membuktikan bahwa terdapat pengaruh yang positif persepsi mahasiswa tentang micro teachingdan bimbingan guru pamong terhadap kemampuan mengajar mahasiswa PPL. Juga mendukung penelitian yang dilakukan oleh Amin Fadly (2015) yang membuktikan bahwa terdapat pengaruh yang positif dan signifikan prestasi belajar micro teaching dan bimbingan guru pamong terhadap kemampuan mengajar PPL.

\section{PENUTUP}

\section{Simpulan}

Berdasarkan analisis data terbukti bahwa 1) Nilai $\mathrm{t}_{\text {Hitung }} \mathrm{X} 1$ terhadap $\mathrm{Y}$ sebesar $(4,930)>t_{\text {Tabel }}(2,000)$ serta tingkat signifikansi $0,000<0,05$, dengan demikian Ho ditolak da $\mathrm{Ha}$ diterima, makadapat disimpulkan ada pengaruh positip yang signifikan antara micro teaching terhadap kemampuan mengajar mahasiswa magang Program Studi Pendidikan Ekonomi STKIP PGRI Tulungagung. 2) Nilai $t$ HitungX2 terhap Y sebesar(2,960) > $\mathrm{t}$ Tabel $(2,000)$ serta tingkat signifikansi $0,000<0,05$. Dengan demikian Ho ditolak dan Ha diterima. maka dapat disimpulkan bahwa ada pengaruh positip yang signifikan antara bimbingan guru pamong terhadap kemampuan mengajar mahasiswa magang Program Studi Pendidikan
Ekonomi. 3) Secara bersama-sama ada pengaruh positif yang signifikan antara micro teaching dan bimbinga guru pamong terhadap kemampuan mengajar mahasiswa magang Program Studi Pendidikan Ekonomi STKIP PGRI Tulungagungsebesar 44,2 sedangkan sebesar 55,8\% dipengaruhi oleh faktor lain. Sedangkan variabel paling dominan berpengaruh adalah variabel $\mathrm{X} 1$ micro teaching .

\section{Saran}

STKIP PGRI Tulungagung Khususnya Perlu peningkatan kualitas pembelajaranmicro teaching kepada mahasiswa sehingga mampu menerapkan ketrampilan dasar mengajar sebagai bekal pelaksanaan magang. Selain itu perlu peningkatan kerjasama baik dengan mitra sekolah yang ditempati magang. Dengan kerjasama yang baik ini akan mendukung pelayanan baik dari pihak mitra sekolah dalam pelaksanaan kegiatan magang.

\section{DAFTAR PUSTAKA}

Amin Fadly. 2015. Prosiding Semiar Nasional Pendidikan Ekonomi \& Bisnis Fakultas Keguruan dan Ilmu Pendidikan Universitas Sebelas Maret Surakarta Sabtu, 07 November 2015ISBN: 978602-8580-19-9. Pengaruh Prestasi Micro teaching dan bimbingan guru pamong terhadap kemampuan mengajar Mahasiswa dalam Program Pengalaman Lapangan (PPL) 
Prodi Pendidikan tataniaga $F E$ Universitas

Dea Natalia S.2013Jupe UNS, Vol 1, No 1, Hal 1 s/d 11., Pengaruh Micro Teaching dan Bimbingan Guru Pamong terhadap Kemampuan Mengajar Mahasiswa PPL FKIP UNS Surakarta.April, 2013. Pendidikan Ekonomi-BKK Akuntansi, FKIP Universitas Sebelas Maret Surakarta, 57126, Indonesia

Das Salirawati. 2011. Teori Micro Teaching. Makalah Bimbingan Teknis Tenaga Pelatih Konservasi dan Pemugaran, Direktorat Jenderal Sejarah dan Purbakala

Fahmi Ulin Ni'mah dan Nina Oktarina, 2014.Economic Education Analysis Journal EEAJ 3 (2) 2014 ISSN 2252 6544 Jurusan Pendidikan Ekonomi, Fakultas Ekonomi, Universitas Negeri Semarang, Indonesia akses 8 pebruari 2016

Fitria Novitasari.2013. Jupe UNS, Vol 1 No 2 Hal 1 s/d 13. Pengaruh Program Pengalaman Lapangan Terhadap Kesiapan Mahasiswa Prodi Ekonomi FKIP UNS Menjadi Tenaga Pendidik| Juni, 2013. Program studi Pendidikan Ekonomi BKK Akuntansi, FKIP Universitas Sebelas Maret Surakarta, 57126, Indonesia.
Mukhibad, H dan Susilowati, N. 2010.Jurnal Lembaran Ilmu Kependidikan, 39 (2), 112-124. Studi Evaluasi Kompetensi Mengajar Mahasiswa Praktek Pengalaman Lapangan (PPL) Jurusan Akuntansi Universitas Negeri Semarang.

Najjah, Wi Indah Subkhiyatin. Skripsi (2014) Pengaruh Nilai Micro Teaching TerhadapKemampuan Mengajar Praktek PengalamanLapangan (PPL) Mahasiswa S1 Program StudiTadris Biologi Angkatan 2010 Fakultas IlmuTarbiyah dan Keguruan IAIN Walisongo Semarang akses 8 pebruari 2016.

Dasmo. 2014. Jurnal Formatif 4(1): 56-64, 2014 ISSN: 2088-351X Peran Guru Pamong dan Dosen pembimbing terhadap keberhasilan program pengalaman lapangan (PPL). MahasiswaProgram Studi Pendidikan Fisika, Fakultas Teknik, Matematika \& Ilmu Pengetahuan Alam Universitas Indraprasta PGRI.

Sulthon, 2009. Manajemen Pengajaran Mikro. Yogyakarta: Laks Bang PRESS Sindo.

Sumaryati T. Program Studi Bimbingan Konseling, Fakultas Ilmu Pendidikan dan Pengetahuan Sosial Universitas Indraprasta PGRI. 
Syed Manzoor Hussain Shah \& Rehana Masrur. 2011. Impact of Micro Teaching Skills on The Performance of Primary School Teachers. Vol. 27, No. 1: 1529.Negeri Medan akses 8 bpebruari 2016

Supri Wahyudi Utomo.2012. Pendidikan Akuntansi IKIP PGRI Madiun ASSET: Jurnal
Akuntansi dan Pendidikan, Volume 1, Nomor 1, Oktober 2012 pengaruh prestasi belajar perencanaan pengajaran dan micro teaching terhadap praktik pengalaman lapangan mahasiswa pendidikan akuntansi IKIP PGRI Madiun. akses 8 bpebruari 2016. 